\title{
DYNAMICS OF PRODUCTION AND FOREIGN TRADE OF RUSSIA ${ }^{1}$
}

\author{
A.Knobel, A.Firanchuk
}

Export and import value indices were synchronous in their decline throughout the past year, 2015. The behavior of exports was naturally shaped by the plunge of prices of raw materials (even though their physical volume remained roughly the same), while the declining value of imports was caused by the shrinkage, by one quarter, of their physical volume and the slight decline of the average dollar prices of inward moving goods, including due to the US dollar's rise against practically all world currencies. In January 2016, the shrinkage of imports and exports continued; more particularly, the plunge of exports was deeper, and the balance of trade hit its record low of the last few years $-\$ 8.5 \mathrm{bn}$.

\section{The Behavior of Exports and Imports Total Imports and Exports}

In 2015, exports and imports continued their synchronous plunge (Fig. 1). Export value shrank to $\$ 343.4 \mathrm{bn}$ (to $69.0 \%$ on 2014 ), imports plunged deeper in relative terms - to $\$ 182.4 \mathrm{bn}(63.6 \%)$, the balance of trade in commodities also shrank to $\$ 161.2 \mathrm{bn}$ (76.3\%). A slight recovery of imports and exports (relative to the corresponding month of 2014) observed over H2 2015 is by no means a manifestation of a U-turn in the general trend. Instead, this phenomenon can be explained by the low base effect, as the noticeable plunge of trade indices had begun in $\mathrm{H} 22014$.

In part, the shrinkage of foreign trade volume in terms of value can be explained by the surge, in 2015, of the USD exchange rate against the world's

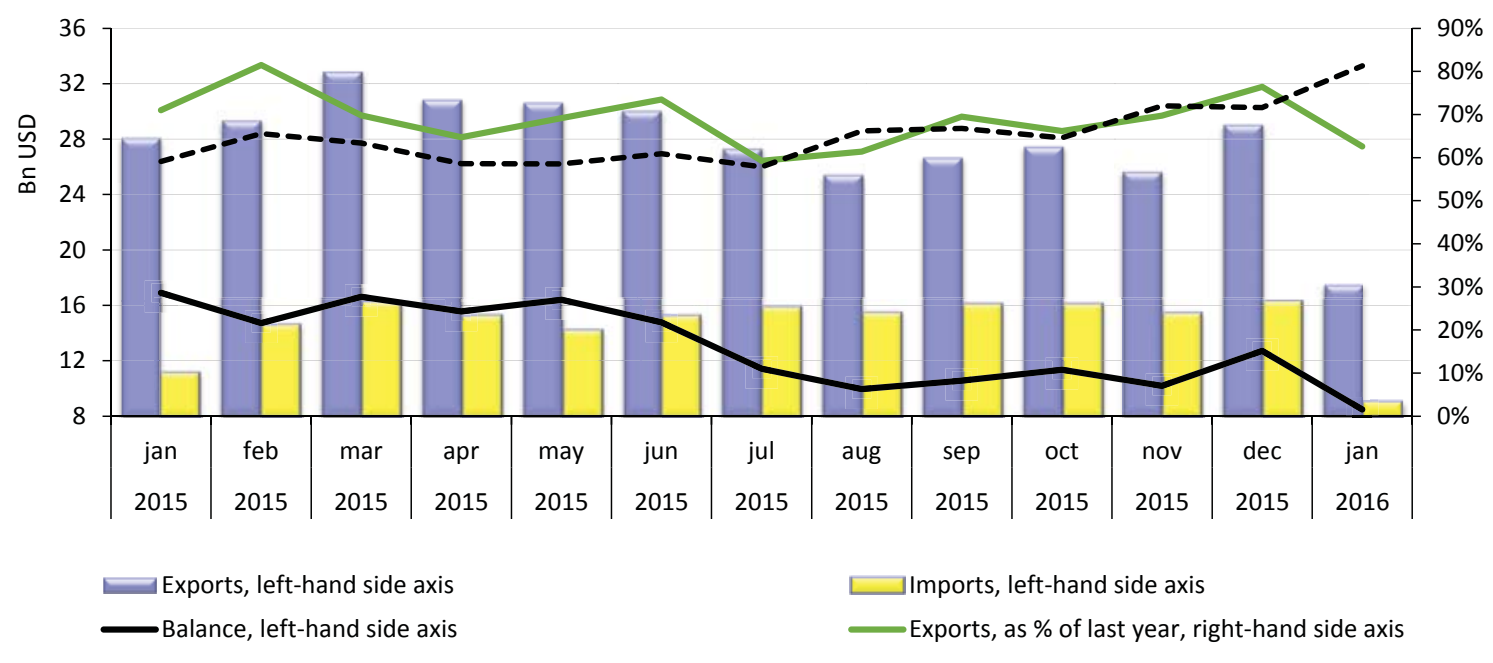

Source: own calculations based of the Federal Tax Service's data.

Fig. 1. The Behavior of Russia's Foreign Trade in 2015

1 This paper was originally published in Online Monitoring of Russia's Economic Outlook No.4(22). 
major currencies ${ }^{1}$ (by $17 \%$ against the Euro, by $13 \%$ against the yen, and by $7 \%$ against GBP). Thus, when Russia's foreign trade value is recalculated in euro terms (the euro being the national currency of her major partners in trade), it can be seen that the shrinkage of import value in 2015 amounted to $23.7 \%$, that of export value - to $17.2 \%$, that of the trade balance - to $8.4 \%$, and that of non-fuel export value (less Group 27 of the Commodity Classification of Foreign Economic Activity (CC FEA) remained practically unchanged

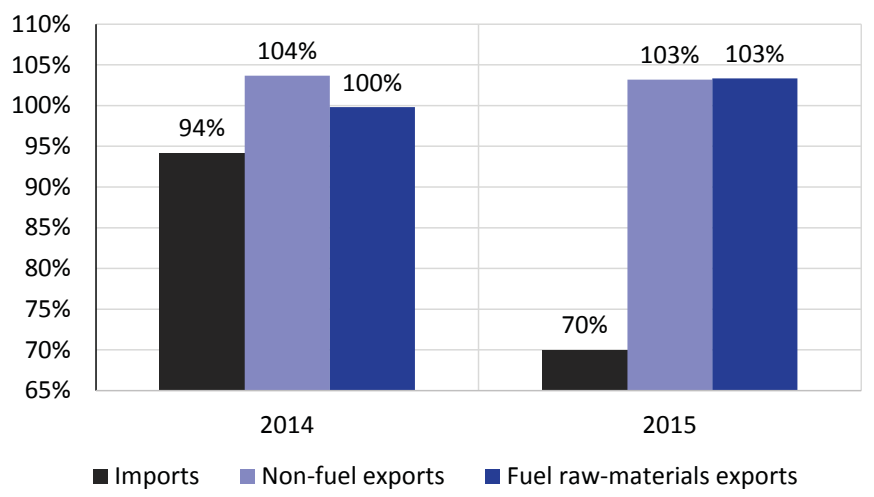

Source: own calculations based of the Federal Tax Service's data.

Fig. 2. The Behavior of Russia's Imports and Exports, in Terms of Physical Volume, as \% of 2013 (growth by a mere $0.4 \%$ ).

An analysis of Russia's trade valuated at 2013 prices less the classified commodity group (Fig. 2) indicates that the physical volume of exports did not change in any significant way. Thus, exports of fuel raw materials (Commodity Classification of Foreign Economic Activity (FEACN of the CU 27) rose in 2015 by $2.8 \%$, while non-fuel exports shrank by only $0.5 \%$. At the same time, the volume of imports in 2015 (at constant 2013 prices) plunged sharply by $25.7 \%$.

\section{The structure of imports, and exports, by commodity type and geographic distribution}

The shares of major commodity groups in total imports in 2014 and 2015 were sufficiently stable (Fig. 3). The deepest plunge of imports was observed in the following groups: Transport means (FEACN of the CU 86-89) - to \$18.0bn (51.5\% of 2014) and Metals, gemstones and precious metal articles (FEACN of

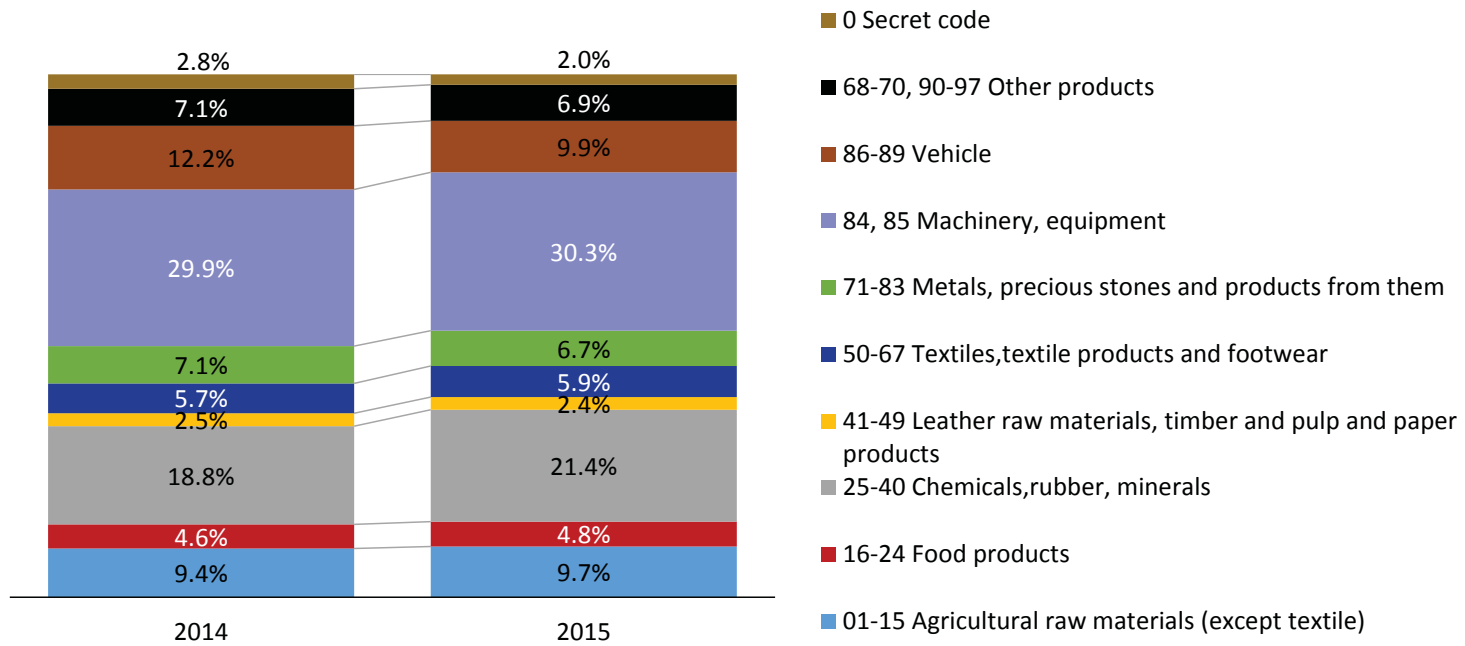

Source: own calculations based of the Federal Tax Service's data.

Fig. 3. The Structure of Russia's Imports in 2014-2015

1 The average foreign exchange rate in dollar terms in 2015 compared to 2014. See IMF, https://www.imf.org/external/np/fin/ert/GUI/Pages/CountryDataBase.aspx 


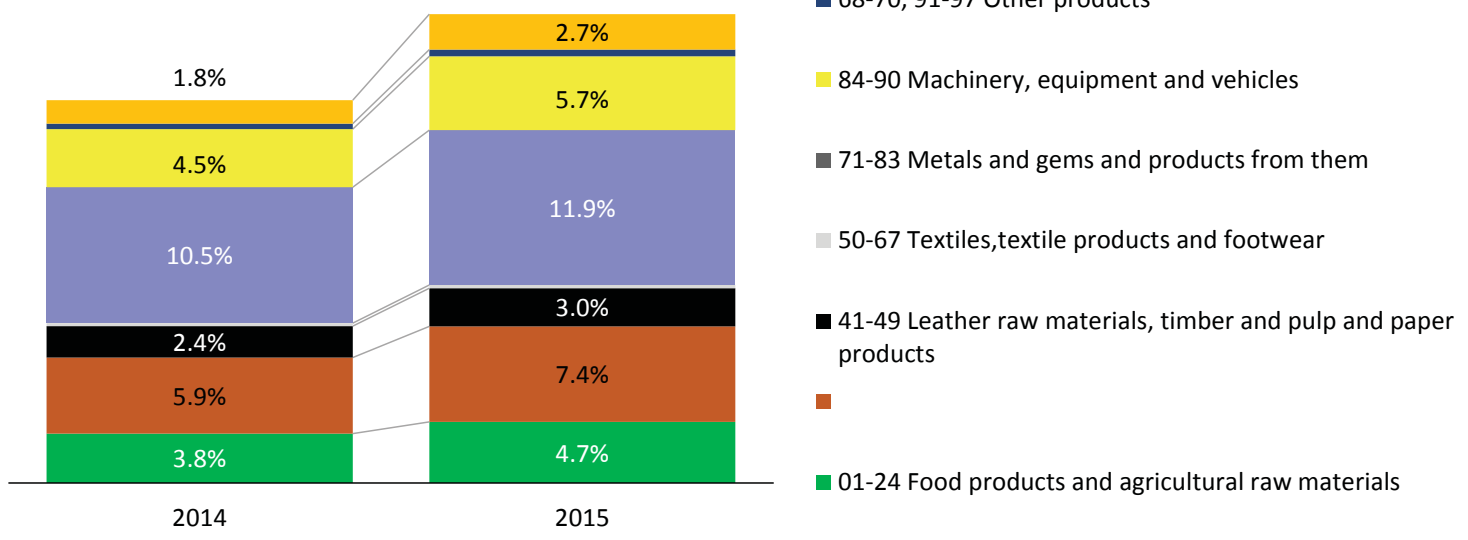

0 Secret code

68-70, 91-97 Other products

84-90 Machinery, equipment and vehicles

71-83 Metals and gems and products from them

50-67 Textiles, textile products and footwear

41-49 Leather raw materials, timber and pulp and paper products

01-24 Food products and agricultural raw materials

Source: own calculations based of the Federal Tax Service's data.

Fig. 4. Structure of Russia's Exports in 2014-2015

the CU 71-83) - to $\$ 12.3 \mathrm{bn}(60.1 \%)$; the least decline of imports occurred in the group Chemical industry products, mineral raw materials (FEACN of the CU $25-40$ ) - to $\$ 38.9 \mathrm{bn}(72.3 \%)$. The other commodity groups demonstrated nearly similar import behavior indices which varied between $61 \%$ and $67 \%$ of 2014, which points to the similarity of factors influencing the movement of imports: the weakening ruble and the declining business activity.

The shares of major commodity groups (other than mineral products) in total exports were following a similar pattern in 2014 and 2015 (Fig. 4). The

Table 1

THE GEOGRAPHIC STRUCTURE OF RUSSIA'S FOREIGN TRADE

\begin{tabular}{|c|c|c|c|c|c|c|c|c|c|c|c|c|}
\hline \multirow[b]{2}{*}{ Region/country } & \multicolumn{4}{|c|}{ Imports } & \multicolumn{4}{|c|}{$\begin{array}{l}\text { Exports of mineral fuel } \\
\text { (FEACN of the CU 27) }\end{array}$} & \multicolumn{4}{|c|}{ Other exports } \\
\hline & 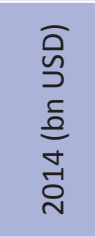 & 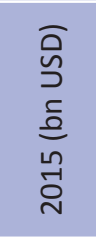 & 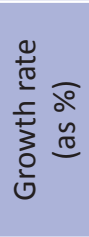 & 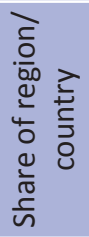 & 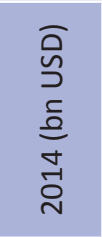 & 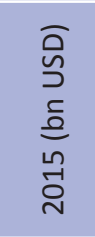 & 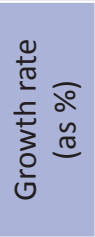 & 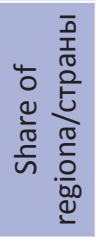 & 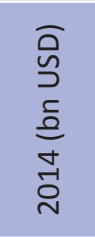 & 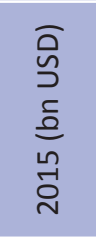 & 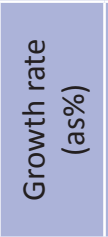 & 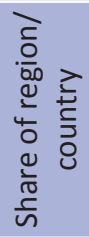 \\
\hline EAEU & 20.0 & 13.6 & 68.1 & 7.5 & 14.5 & 11.2 & 77.0 & 5.2 & 20.6 & 15.8 & 76.5 & 12.4 \\
\hline Armenia & 0.3 & 0.2 & 62.6 & 0.1 & 0.7 & 0.6 & 90.6 & 0.3 & 0.4 & 0.4 & 104.1 & 0.3 \\
\hline Belarus & 12.3 & 8.6 & 70.3 & 4.7 & 11.8 & 9.0 & 76.0 & 4.1 & 8.2 & 6.3 & 76.6 & 4.9 \\
\hline Kazakhstan & 7.4 & 4.8 & 64.5 & 2.7 & 2.0 & 1.6 & 78.0 & 0.7 & 12.1 & 9.1 & 75.6 & 7.2 \\
\hline CIS & 13.1 & 7.4 & 56.3 & 4.0 & 13.6 & 6.8 & 49.9 & 3.1 & 16.1 & 11.9 & 73.7 & 9.3 \\
\hline Ukraine & 10.7 & 5.7 & 52.8 & 3.1 & 10.3 & 4.2 & 41.2 & 2.0 & 6.8 & 5.1 & 74.7 & 4.0 \\
\hline Europe & 124.7 & 74.2 & 59.5 & 40.7 & 218.0 & 131.7 & 60.4 & 60.9 & 48.2 & 39.3 & 81.6 & 30.9 \\
\hline EC & 118.5 & 70.1 & 59.2 & 38.5 & 215.3 & 129.5 & 60.2 & 60.0 & 43.9 & 36.1 & 82.2 & 28.3 \\
\hline $\begin{array}{l}\text { North and } \\
\text { South America }\end{array}$ & 30.3 & 20.1 & 66.2 & 11.0 & 5.0 & 3.9 & 78.8 & 1.8 & 13.8 & 11.6 & 84.6 & 9.1 \\
\hline USA & 18.5 & 11.4 & 61.9 & 6.3 & 3.8 & 3.0 & 79.8 & 1.4 & 6.8 & 6.5 & 95.9 & 5.1 \\
\hline $\begin{array}{l}\text { Asia and } \\
\text { Oceania }\end{array}$ & 95.7 & 64.8 & 67.7 & 35.5 & 92.6 & 61.4 & 66.3 & 28.4 & 46.0 & 41.1 & 89.3 & 32.3 \\
\hline China & 50.9 & 34.9 & 68.7 & 19.2 & 27.8 & 18.9 & 68.1 & 8.7 & 9.7 & 9.7 & 99.5 & 7.6 \\
\hline Japan & 10.9 & 6.8 & 62.4 & 3.7 & 17.2 & 11.9 & 69.3 & 5.5 & 2.7 & 2.6 & 97.0 & 2.0 \\
\hline Aftica & 2.8 & 2.3 & 83.3 & 1.3 & 2.4 & 1.1 & 45.7 & 0.5 & 7.0 & 7.7 & 110.5 & 6.0 \\
\hline Total & 286.7 & 182.3 & 63.6 & & 346.1 & 216.1 & 62.4 & & 151.7 & 127.4 & 84.0 & \\
\hline
\end{tabular}

Source: own calculations based of the Federal Tax Service's data. 


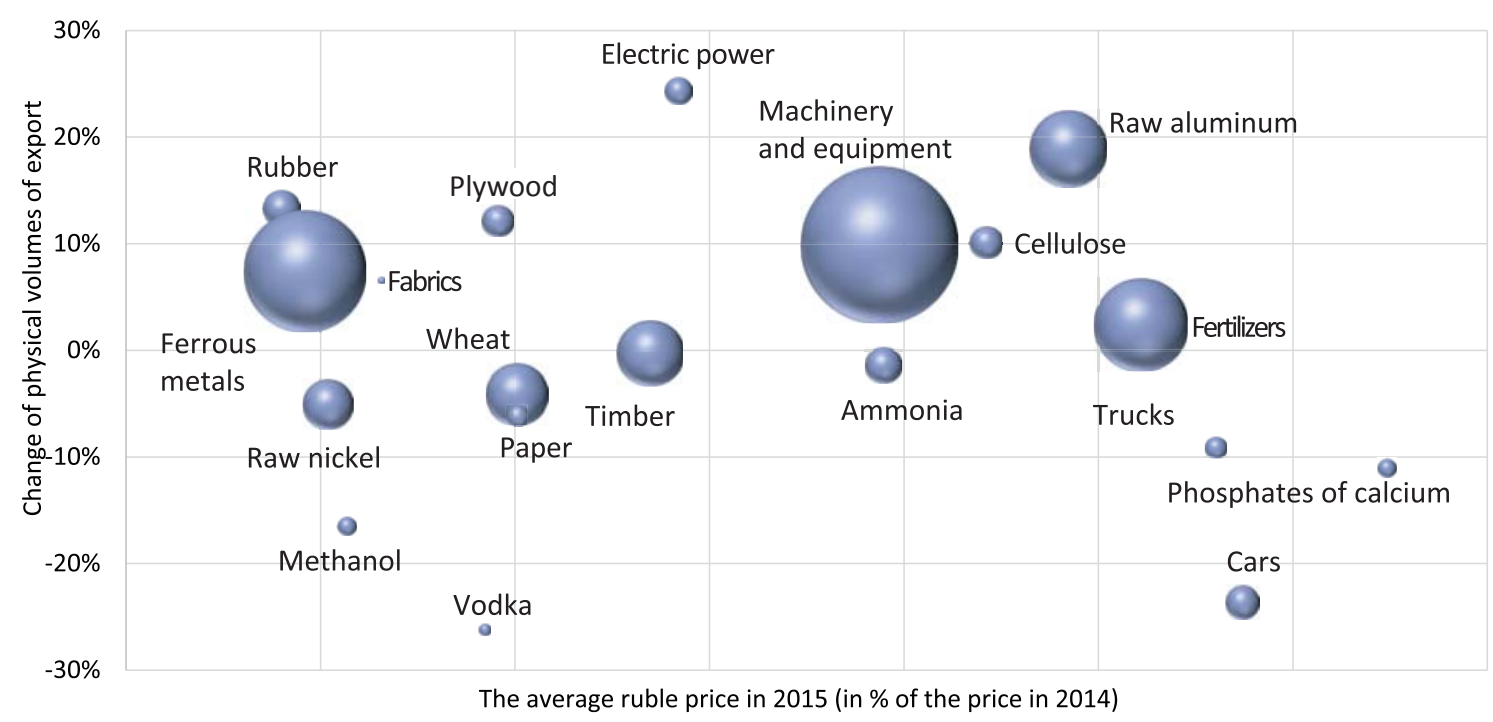

Source: own calculations based on data released by the Federal Tax Service and the RF Central Bank.

Note. The size of each circle in proportional to the export value index.

Fig. 5. The Dispersion of Changes Displayed by Russia's Exports in 2015, in Terms of Physical Volume, and the Average Price, in Rubles

steepest decline was observed in the group Mineral products (FEACN of the CU $25-27)$ - to $\$ 219.3 \mathrm{bn}$ (62.5\% of 2014), and their share in total exports shrank to $63.8 \%$ vs. $70.5 \%$ a year earlier. The least decline of exports was observed in the groups Machines, equipment and transport means (FEACN of the CU 84-90) - to $\$ 19.6 \mathrm{bn}$ (88.0\% on 2014) and Chemical industry products, mineral raw materials (FEACN of the CU 25-40) - to $\$ 25.3 \mathrm{bn}(86.7 \%)$. The other commodity groups demonstrated approximately similar results $-77 \%$ to $85 \%$ of 2014.

The geographic structure of Russia's foreign trade is shown in Table 1. The share of the EAEU in Russia's total commodity turnover somewhat increased. However, in 2015, Russian non-fuel exports to EAEU markets shrank significantly- by $25.5 \%$, while the decline of exports of fuel raw materials was less steep.

The behavior of trade with the other post-Soviet states, as before, is determined by that of Russia's trade with Ukraine, whose commodity turnover shrank by $46.2 \%$.

The index of trade with the EU is slightly below the average index of Russia's total foreign trade volume. The steeper decline of imports has been caused, among other things, by the food embargo introduced in August 2014. The index of exports to the USA is noteworthy for its higher stability: exports of mineral fuel shrank by $20.2 \%$, while other exports - by a mere $4.1 \%$. This can be explained first of all by the rising exports of non-organic chemical products (by $5 \%$ ), fertilizers (by $39 \%$ ) and aluminum (by $5 \%$ ).

The volume of non-fuel exports remained practically unchanged with regard to China (-0.5\%) and Japan $(-3.0 \%)$, while with regard to the countries of Africa it increased (by $10.5 \%$ ).

\section{A comparative analysis of changes in average price and export volume}

A comparative analysis of the behavior, in 2015, of average ruble-denominated export prices and export volume (Fig. 5) point to growth of exports, in terms of physical volume, of many commodity types. At the same time, 
Table 2

TRADE AND OUTPUT VOLUME INDICES IN RUSSIA IN 2015 COMPARED TO 2014, WITH REGARD TO SOME TYPES OF AGRICULTURAL PRODUCTS AND FINISHED FOODSTUFFS

\begin{tabular}{|c|c|c|c|c|c|c|c|}
\hline \multirow[b]{2}{*}{$\begin{array}{l}\text { Rosstat's Commodity Code - cor- } \\
\text { responding FEACN of the CU Code }\end{array}$} & \multirow{2}{*}{ 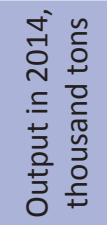 } & \multicolumn{2}{|c|}{ Change in output } & \multicolumn{2}{|c|}{ Change in imports } & \multicolumn{2}{|c|}{ Change in exports } \\
\hline & & $\begin{array}{l}\text { Physical vol- } \\
\text { ume, thou- } \\
\text { sand tons }\end{array}$ & as $\%$ & $\begin{array}{l}\text { Physical vol- } \\
\text { ume, thou- } \\
\text { sand tons }\end{array}$ & as $\%$ & $\begin{array}{l}\text { Physical vol- } \\
\text { ume, thou- } \\
\text { sand tons }\end{array}$ & as $\%$ \\
\hline $\begin{array}{l}\text { Slaughtered animal meat } \\
\text { and subproducts - FEACN of } \\
\text { the CU: } 0201-0206,0209\end{array}$ & 1987.6 & 258.4 & 13.0 & -318.8 & -26.5 & 7.7 & 48.2 \\
\hline $\begin{array}{l}\text { Poultry mean and subproduct food- } \\
\text { stuffs - FEACN of the CU: } 0207\end{array}$ & 3941.6 & 378.4 & 9.6 & -201.1 & -44.3 & 11.9 & 19.3 \\
\hline $\begin{array}{l}\text { Fish (other than canned } \\
\text { fish) - FEACN of the CU: } 03\end{array}$ & 2911.0 & 198.0 & 6.8 & -289.3 & -38.1 & 28.7 & 2.2 \\
\hline $\begin{array}{l}\text { Unrefined sunflower oil and its frac- } \\
\text { tions - FEACN of the CU: } 1512\end{array}$ & 4023.1 & -362.1 & -9.0 & -5.4 & -61.5 & -231.0 & -13.8 \\
\hline $\begin{array}{l}\text { Wheat and wheat-and-rye } \\
\text { flour- FEACN of the CU: } 1101\end{array}$ & 8925.5 & 178.5 & 2.0 & -10.5 & -29.5 & 138.4 & 110.4 \\
\hline
\end{tabular}

no significant correlation between the upward movement of average rubledenominated prices ${ }^{1}$ and physical volume of exports could be traced.

\section{A Comparison of the Behavior of Trade and Output for Some Commodity Types}

Table 2-4 demonstrates the comparative changes, in terms of physical volume, in the behavior of Russia's output (based on Rosstat's data) and that of Russia's foreign trade (based on data released by the Federal Tax Service).

\section{Agriculture and food industry}

A comparative analysis of a sample of major groups of agricultural output and the food industry demonstrates that a change in the trade balance, in

TRADE AND OUTPUT VOLUME INDICES IN RUSSIA IN 2015 COMPARED TO 2014, WITH REGARD TO SOME TYPES OF LOW VALUE ADDED INDUSTRIAL PRODUCTS

\begin{tabular}{|c|c|c|c|c|c|c|c|}
\hline \multirow[b]{2}{*}{$\begin{array}{l}\text { Rosstat's Commodity Code - cor- } \\
\text { responding FEACN of the CU Code }\end{array}$} & \multirow{2}{*}{ 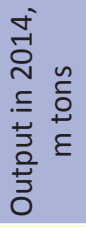 } & \multicolumn{2}{|c|}{ Change in output } & \multicolumn{2}{|c|}{ Change in imports } & \multicolumn{2}{|c|}{ Change in exports } \\
\hline & & $\begin{array}{c}\text { Physical } \\
\text { volume, } \\
\text { m tons }\end{array}$ & $\%$ & $\begin{array}{l}\text { Physical vol- } \\
\text { ume, } \mathrm{m} \text { tons }\end{array}$ & $\%$ & $\begin{array}{l}\text { Physical vol- } \\
\text { ume, } \mathrm{m} \text { tons }\end{array}$ & $\%$ \\
\hline $\begin{array}{l}\text { Plastics, primary forms - FEACN } \\
\text { of the CU: } 3901-3914\end{array}$ & 6.68 & 0.54 & 8.1 & -0.73 & -24.3 & 0.21 & 16.8 \\
\hline Pig iron - FEACN of the CU: 7201 & 51.4 & 2.26 & 4.4 & 0.00 & & 0.98 & 22.5 \\
\hline $\begin{array}{l}\text { Gasoline (light distillates) - } \\
\text { FEACN of the CU: } 271012\end{array}$ & 38.3 & 0.9 & 2.3 & -0.9 & -55.3 & 1.0 & 3.7 \\
\hline $\begin{array}{l}\text { Diesel fuel - FEACN of the CU: } \\
27101942,27101946,27101948\end{array}$ & 76.7 & -0.8 & -1.1 & 0.0 & & 2.9 & 6.0 \\
\hline $\begin{array}{l}\text { Fuel oil - FEACN of the CU: } \\
27101966,27101964,27101962\end{array}$ & 78.5 & -7.0 & -8.9 & 0.0 & & 7.9 & 12.0 \\
\hline
\end{tabular}

1 Prices in dollar terms (based on data released by the Federal Tax Service) were recalculated by the average foreign exchange rate set by the RF Central Bank. 
terms of physical volume, in most cases is significantly offset by a corresponding change in output. However, output growth is higher than the growth of the trade balance only with regard to poultry meat and flour. The imports of these commodity groups declined significantly (by tens of percents), while exports moved in the same direction as output. It should be noted that the consumption $^{1}$ of poultry meat increased (by 165,000 tons), while that of slaughtered animal meat decreased (by 68,000 tons), as did the consumption of fish, with the exception of canned products (by 120,000 tons). This fact points to the replacement, in the consumer basket, of the more expensive animal meat and fish by poultry meat.

\section{Low value added industrial products}

A comparative analysis of a sample of major low value added industrial products (Table 3 ) indicates that in 2015, their imports declined significantly while exports increased, and that the movement of output was multi-vectored.

\section{Transport means, household utensils, footwear}

The outputo indices for the main types of transport means, household utensils and footwear demonstrated two-digit percentage decline (Table 4). Imports, in terms of physical volume, of footwear shrank by $1 / 5$, of household utensils - by 1.5 times, transport means - by 2-4 times. Exports of buses and coaches, passenger and freight automobiles also declined sharply, but this decline is negligible when compared to imports and output. These data point to the dwindling demand for automobiles and household utensils (refrigerators and receivers).

\section{TRADE AND OUTPUT VOLUME INDICES IN RUSSIA IN 2015 COMPARED TO 2014, WITH REGARD} TO SOME TYPES OF TRANSPORT MEANS, HOUSEHOLD UTENSILS AND FOOTWEAR

\begin{tabular}{|c|c|c|c|c|c|c|c|}
\hline \multirow{2}{*}{$\begin{array}{l}\text { Rosstat's Commodity } \\
\text { Code - corresponding } \\
\text { FEACN of the CU Code }\end{array}$} & \multirow{2}{*}{ 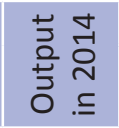 } & \multicolumn{2}{|c|}{ Change in output } & \multicolumn{2}{|c|}{ Change in imports } & \multicolumn{2}{|c|}{ Change in exports } \\
\hline & & $\begin{array}{l}\text { Physical } \\
\text { volume }\end{array}$ & $\%$ & $\begin{array}{l}\text { Physical } \\
\text { volume }\end{array}$ & $\%$ & $\begin{array}{l}\text { Physical } \\
\text { volume }\end{array}$ & $\%$ \\
\hline $\begin{array}{l}\text { Tractors for agriculture, forestry, } \\
\text { etc. - FEACN of the CU: } 870190 \text {, } \\
870120 \text { (thousand units) }\end{array}$ & 6.75 & -1.61 & -23.8 & -24.81 & -51.9 & 0.88 & 29.4 \\
\hline $\begin{array}{l}\text { Freight carriages - FEACN of } \\
\text { the CU: } 8606 \text { (thousand units) }\end{array}$ & 55.15 & -25.15 & -45.6 & -3.45 & -71.1 & 3.62 & 64.5 \\
\hline $\begin{array}{l}\text { Buses and coaches - FEACN of } \\
\text { the CU: } 8702 \text { (thousand units) }\end{array}$ & 44.22 & -7.52 & -17.0 & -3.61 & -75.5 & -1.40 & -41.2 \\
\hline $\begin{array}{l}\text { Freight automobiles (includ- } \\
\text { ing chassis) - FEACN of the } \\
\text { CU: } 8704 \text { (thousand units) }\end{array}$ & 153.58 & -22.58 & -14.7 & -39.04 & -63.4 & -2.45 & -10.9 \\
\hline $\begin{array}{l}\text { Passenger automobiles - FEACN } \\
\text { of the CU: } 8703 \text { ( } m \text { units) }\end{array}$ & 1.68 & -0.46 & -27.7 & -0.35 & -50.3 & -0.03 & -24.6 \\
\hline $\begin{array}{l}\text { Refrigerators and freezers } \\
\text { for household use - FEACN } \\
\text { of the CU: } 8418 \text { (m units) }\end{array}$ & 3.70 & -0.59 & -15.8 & -0.74 & -32.2 & -0.07 & -11.3 \\
\hline $\begin{array}{l}\text { Television sets (receivers) - } \\
\text { FEACN of the CU: } 8528 \text { (m units) }\end{array}$ & 16.11 & -7.48 & -46.4 & -8.39 & -35.9 & -0.54 & -33.6 \\
\hline $\begin{array}{l}\text { Footwear - FEACN of } \\
\text { the CU: } 64 \text { (m pairs) }\end{array}$ & 108.14 & -17.84 & -16.5 & -51.48 & -19.9 & 0.004 & 0.0 \\
\hline
\end{tabular}

1 The difference between domestic output and trade balance. 